\title{
Diagnostic value of selected biochemical markers in the detection of recurrence of medullary thyroid cancer - comparison of calcitonin, procalcitonin, chromogranin A, and carcinoembryonic antigen
}

\author{
Wartość diagnostyczna wybranych markerów biochemicznych w diagnostyce \\ wznowy raka rdzeniastego tarczycy — porównanie kalcytoniny, prokalcytoniny, \\ chromograniny A i antygenu karcynoembrionalnego
}

Kosma Woliński, Jarosław Kaznowski, Aleksandra Klimowicz, Adam Maciejewski, Dagny Łapińska-
-Cwojdzińska, Edyta Gurgul, Adrian D. Car, Marta Fichna, Paweł Gut, Maria Gryczyńska, Marek Ruchała

Department of Endocrinology, Metabolism and Internal Medicine, Poznań University of Medical Sciences

\begin{abstract}
Introduction: Medullary thyroid cancer (MTC) is a malignancy of the thyroid gland, which derives from parafollicular C cells. Periodic measurement of biochemical markers of MTC remains a crucial part of patient follow-up and disease monitoring. The aim of the study was to compare the diagnostic value of four selected markers - calcitonin (Ct), procalcitonin (PCT), chromogranin A (CgA), and carcinoembryonic antigen (CEA). Material and methods: Patients with histopathologically confirmed MTC hospitalised in a single department between January 2015 and December 2015 were included in the study. Patients were subdivided into two groups: a remission group and an active disease group, based upon serum markers of MTC and imaging. Levels of Ct, PCT, CgA, and CEA were compared between the groups.

Results: Forty-four patients were included; 20 patients presented active disease and 24 were in remission. All patients with active disease had Ct exceeding the upper limit of normal range $(10 \mathrm{pg} / \mathrm{mL})$ — for that threshold the sensitivity was $100.0 \%$ and the specificity was $73.9 \%$; for the best-fit threshold of $121.0 \mathrm{pg} / \mathrm{mL}$ the specificity was $95.8 \%$ with sensitivity $100.0 \%$. There was significant correlation between $\mathrm{Ct}$ and PCT $-\mathrm{p}<0.000001, \mathrm{r}=0.93$. All patients with active disease exceeded the upper limit of the normal range $(0.5 \mathrm{ng} / \mathrm{mL})-$ for that threshold the sensitivity was $100.0 \%$ and the specificity was $83.3 \%$; for the best-fit threshold of $0.95 \mathrm{ng} / \mathrm{mL}$ the specificity was $95.8 \%$ with sensitivity $100.0 \%$. In case of CEA for the best-fit threshold of $12.66 \mathrm{ng} / \mathrm{mL}$ the specificity was $100.0 \%$ with sensitivity $57.9 \%$; for CgA the best-fit threshold was $75.66 \mathrm{ng} / \mathrm{mL}$ with specificity $83.3 \%$ and sensitivity $75.0 \%$.

Conclusions: Our study confirms that PCT can be considered as an equivalent alternative for measurement of calcitonin. On the other hand, it is also worth noting that MTC can be a rare cause of very high levels of PTC not resulting from infectious diseases. The diagnostic value of CEA and chromogranin A is much lower and can be within the normal range even in patients with advanced, metastatic MTC. They should be used only as accessory markers. (Endokrynol Pol 2017; 68 (4): 434-437)
\end{abstract}

Key words: procalcitonin, calcitonin, medullary thyroid cancer, chromogranin A, carcinoembryonic antigen

\section{Streszczenie}

Wstęp: Rak rdzeniasty tarczycy (RRT) to nowotwór złośliwy tarczycy wywodzący się z przypęcherzykowych komórek C. Okresowa kontrola markerów biochemicznych RRT stanowi kluczowy element prowadzenia pacjenta i monitorowania choroby. Celem obecnej pracy było porównanie wartości diagnostycznej czterech wybranych markerów — kalcytoniny (Ct), prokalcytoniny (PCT), chromograniny A (CgA) i antygenu karcynoembrionalnego (CEA).

Metody: Do badania włączono pacjentów z histopatologicznie potwierdzonym RRT hospitalizowanych w jednym oddziale szpitalnym w 2015 roku. Pacjentów podzielono na dwie podgrupy — grupę pacjentów w remisji oraz z aktywną chorobą zależnie od wartości markerów osoczowych oraz wykonanej diagnostyki obrazowej.

Wyniki: Włączono czterdziestu czterech pacjentów; 20 pacjentów prezentowało cechy aktywnej choroby, 24 było w remisji. Wszyscy pacjenci z aktywną chorobą wykazywali stężenia Ct przekraczające górną granicę normy (10 pg/ml); dla optymalnego punktu odcięcia 121,0 pg/ml swoistość wyniosła 95,8\% przy czułości 100,0\%. Wykazano istotną korelację pomiędzy Ct i PCT- p $<0.000001$, $\mathrm{r}=0.93$. Dla optymalnego punktu odcięcia wynoszącego $0.95 \mathrm{ng} / \mathrm{ml}$ swoistość wyniosła $95.8 \%$ przy czułości $100.0 \%$. W przypadku CEA dla najlepiej dopasowanego progu $12,66 \mathrm{ng} / \mathrm{ml}$ swoistość wyniosła 100,0\% przy czułości 57,9\%; dla CgA optymalny punkt odcięcia wyniósł 75,66 ng/ml przy swoistości 83,3\% i czułości 75,0\%.

Wnioski: Nasze badanie potwierdza, że PCT może być uważana za równoważną alternatywę dla oznaczenia kalcytoniny. Wartość diagnostyczna CEA i chromograniny A jest znacznie mniejsza i parametry te mogą pozostawać w granicach normy nawet u pacjentów z zaawansowanym RRT z przerzutami odległymi. Powinny być one traktowane jedynie jako pomocnicze markery.

(Endokrynol Pol 2017; 68 (4): 434-437)

Słowa kluczowe: prokalcytonina; kalcytonina; rak rdzeniasty tarczycy; chromogranina A; antigen karcynoembrionalny 


\section{Introduction}

Medullary thyroid cancer (MTC) is a malignancy of the thyroid gland, which derives from parafollicular $C$ cells $[1,2]$. According to numerous studies it accounts for about $1-5 \%$ of all thyroid cancer (TC) and over $10 \%$ of mortalities associated with thyroid malignancies [1-4].

Several aspects of management of MTC remain a challenge. Initial diagnosis may often be delayed because MTCs frequently present as relatively benign lesions on sonographic examination and confounding results of fine-needle aspiration biopsy (FNAB) [5, 6]. Follow-up and detection of recurrence can be challenging, due to common difficulties in localisation of neoplastic masses and discrepancies between results of commonly used biochemical markers [7].

Early detection of MTC recurrence is essential because surgery remains the only effective form of treatment $[1,8,9]$. Periodic measurement of biochemical markers of MTC remains - besides neck ultrasonography - the most important part of the follow-up $[1,2,10]$. The aim of the current study was to compare the diagnostic value of four selected markers - calcitonin $(\mathrm{Ct})$, procalcitonin $(\mathrm{PCT})$, chromogranin $\mathrm{A}(\mathrm{CgA})$, and carcinoembryonic antigen (CEA).

\section{Material and methods}

\section{Patients}

Patients included in the study with histopathologically confirmed MTC were hospitalised in a single department from January 2015 to December 2015. All patients underwent thyroidectomy and were admitted for biochemical and radiological control examinations. Patients were divided into two groups: a remission group and an active disease group based upon several criteria. The criteria used to divide the patients into the groups included MTC serum markers, neck ultrasound examination, chest $\mathrm{X}$-ray, and CT examinations including the neck, chest, and abdomen in the case of abnormal initial examination. The study was approved by the Poznan University of Medical Sciences Ethical Committee. Written informed consent was given by all participants.

\section{Laboratory methods}

$\mathrm{Ct}$ and $\mathrm{CgA}$ were measured using radioimmunological method. CEA and PCT were measured using chemi/ electroluminescent method.

\section{Statistical analysis}

All calculations were performed using Statistica v.12 from Statsoft. A p-value under 0.05 was considered statistically significant. Correlations were calculated using Spearman's rank correlation coefficient due to lack of normal distribution of $\mathrm{Ct}$.

\section{Results}

Forty-four patients were included; there were $27 \mathrm{fe}-$ males and 17 males. Mean age was $55.6 \pm 14.6$ years. Twenty patients presented active disease and 24 were in remission.

\section{Calcitonin}

Patients with active malignancy had calcitonin levels 121.1 up to 65826.0 , median $2548.0 \mathrm{pg} / \mathrm{ml}$, and in patients in remission, $0.5-233.3$, median $3.16 \mathrm{pg} / \mathrm{mL}$. All patients with active disease exceeded the upper limit of normal range $(10 \mathrm{pg} / \mathrm{mL})$ - for that threshold the sensitivity was $100.0 \%$, specificity $73.9 \%$; for the best-fit threshold of $121.0 \mathrm{pg} / \mathrm{mL}$ the specificity was $95.8 \%$ with sensitivity $100.0 \%$ (Fig. 1).

\section{Procalcitonin}

There was significant correlation between $\mathrm{Ct}$ and PCT, $\mathrm{p}<0.000001, \mathrm{r}=0.93$. Patients with active disease had procalcitonin levels ranging from 0.96 to 400.0 , median $23.45 \mathrm{ng} / \mathrm{mL}$. Patients in remission had levels from 0.02 to 1.0 , median $0.04 \mathrm{ng} / \mathrm{dL}$. All patients with active disease exceeded the upper limit of the normal range $(0.5 \mathrm{ng} / \mathrm{mL})$ - for that threshold the sensitivity was $100.0 \%$, specificity $83.3 \%$; for the best-fit threshold of $0.95 \mathrm{ng} / \mathrm{mL}$ the specificity was $95.8 \%$ with sensitivity $100.0 \%$ (Fig. 1).

\section{Carcinoembryonic antigen}

There was a significant correlation between $\mathrm{Ct}$ and CEA $-p<0.000001, r=0.75$. Patients with active disease presented CEA levels from 1.64 to 1000.0, median 21.22 $\mathrm{ng} / \mathrm{mL}$. Patients in remission had levels from 0.52-12.40, median $1.45 \mathrm{ng} / \mathrm{dL}$. Among patients with active disease 13 exceeded the upper limit of normal range $(5 \mathrm{ng} / \mathrm{mL})$ - for that threshold the sensitivity was $65.0 \%$ and the specificity was $79.2 \%$; for the best-fit threshold of $12.66 \mathrm{ng} / \mathrm{mL}$ the specificity was $100.0 \%$ with sensitivity $57.9 \%$ (Fig. 1).

\section{Chromogranin A}

There was significant correlation between $\mathrm{Ct}$ and $\mathrm{CgA}$ $-p=0.000004, r=0.63$. Patients with active disease had CgA levels of 38.0-9127.0, median $125.01 \mathrm{ng} / \mathrm{mL}$. Patients in remission had levels from 26.14-387.95, median $49.1 \mathrm{ng} / \mathrm{mL}$. Among patients with active disease 11 exceeded the upper limit of normal range $(100 \mathrm{ng} / \mathrm{mL})$ - for that threshold the sensitivity was $55.0 \%$ and the specificity was $83.3 \%$; for the best-fit threshold of 75.66 $\mathrm{ng} / \mathrm{mL}$ the specificity was $83.3 \%$ with sensitivity $75.0 \%$ (Fig. 1). 
A

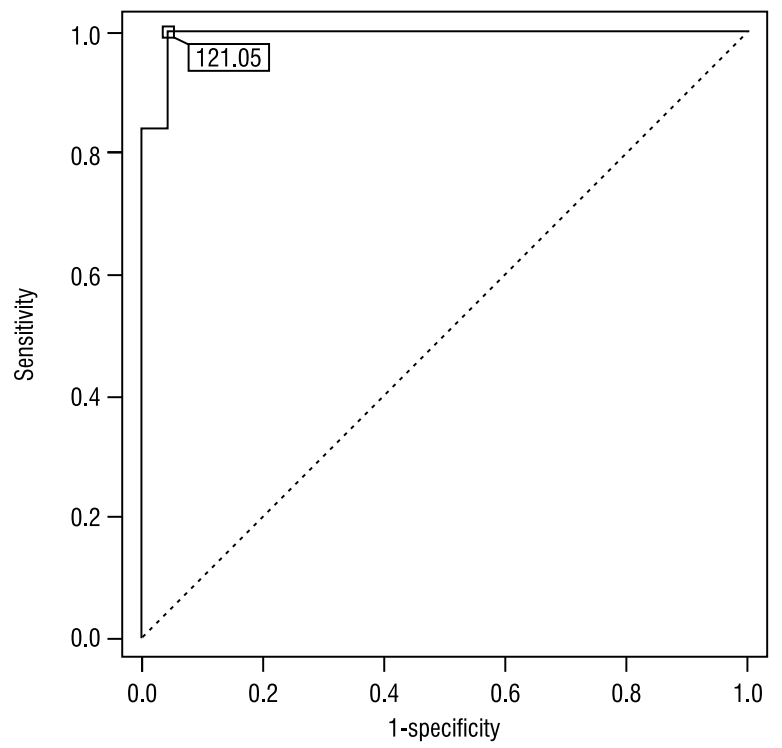

C

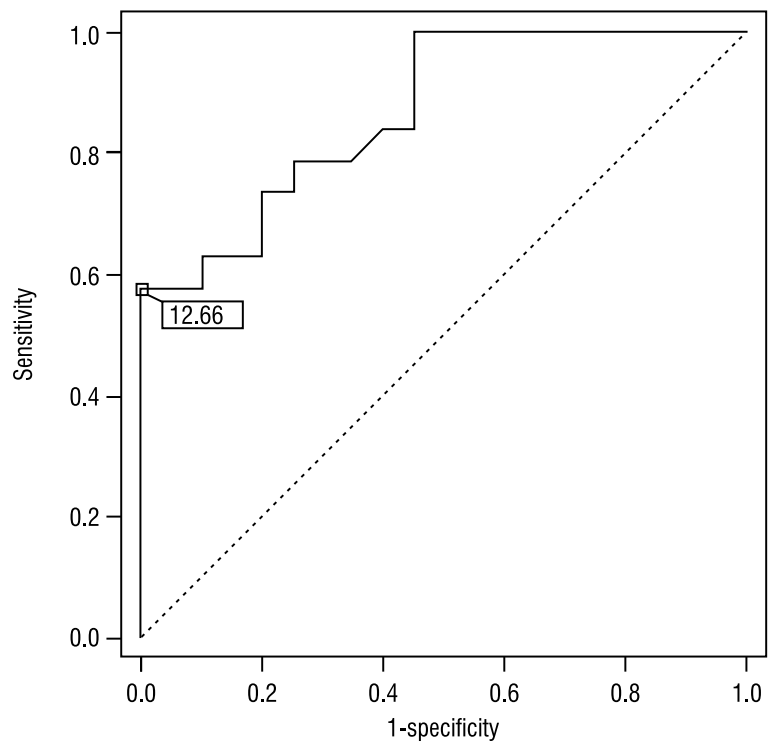

B

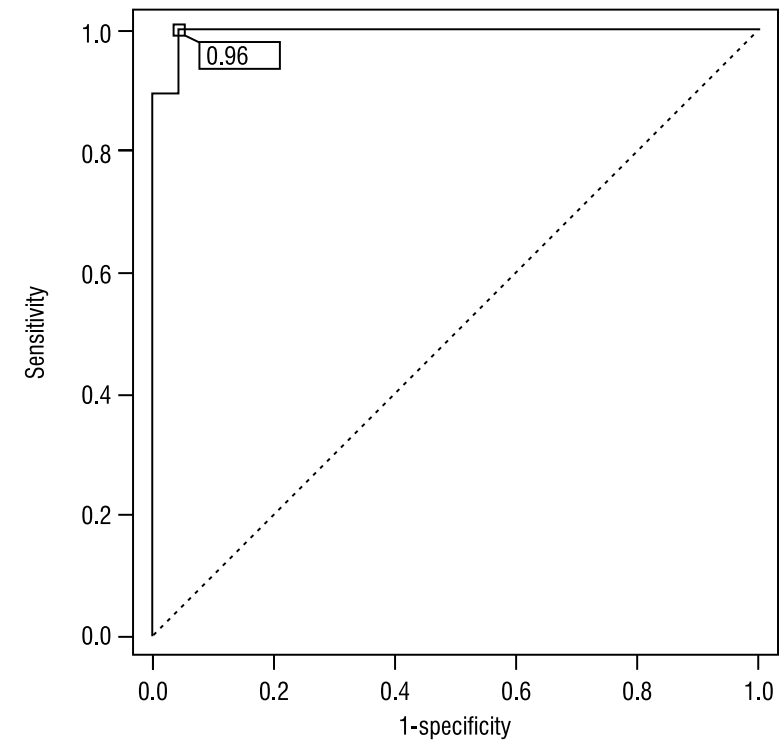

D

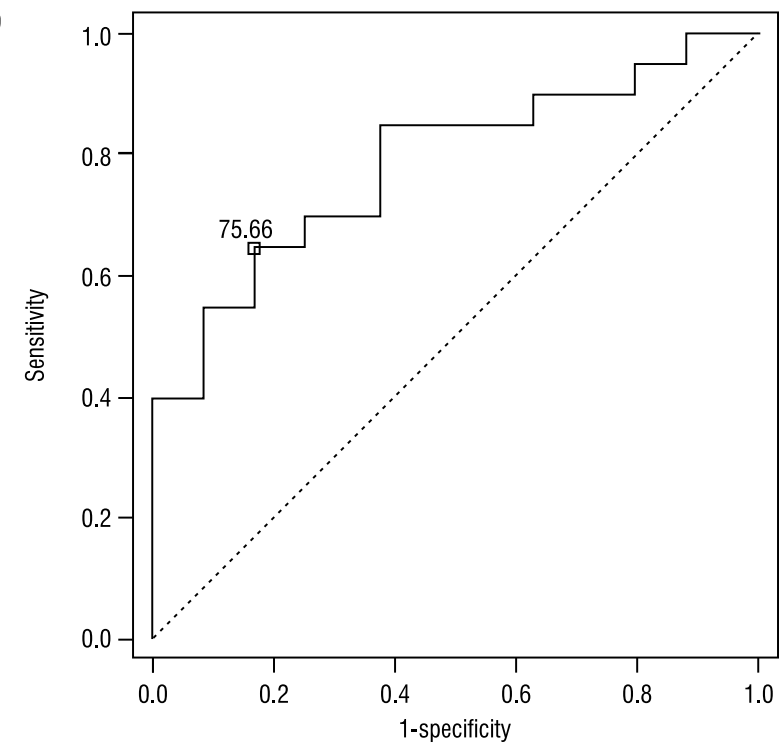

Figure 1. Receiver operating characteristic curves for calcitonin (A), procalcitonin (B), carcinoembryonic antigen (C), and chromogranin $A(D)$ Rycina 1. Krzywa ROC dla kalcytoniny (A), prokalcytoniny (B), antygenu karcynoembrionalnego (C) i chromograniny $A(D)$

\section{Discussion}

Periodic monitoring of serum markers plays a crucial role in the management of patients with MTC and enables early detection of disease recurrence. Calcitonin - as a physiological product of parafollicular C-cells — remains the most sensitive and most commonly used marker, characterised by good correlation with the clinical stage of MTC $[1,2,11,12]$. Procalcitonin is a peptide composed of 116 amino-acids, which is subsequently processed to mature calcitonin containing 32 amino acids. Initially PCT was described as a marker of systemic inflammation, production of which can be stimulated directly by bacterial endotoxins and indirectly by inflammatory mediators [13]. However, PCT — as precursor of $\mathrm{Ct}$ - was also considered as an alternative marker of MTC $[14,15]$. PCT has numerous advantages in comparison to $\mathrm{Ct}$ resulting from biological and practical reasons. It is a very stable protein with an in vivo half live about 20 hours [14]. Its measurement is widely available, eliminating the need for a highly specialised hospital laboratory. Moreover, laboratory sets for PCT are also more readily standardised, and results from different laboratories are easier to compare when contrasted with $\mathrm{Ct}$ because all available sets use the same antibodies, which lends itself to a higher level of performing measurements $[14,16]$. Finally, the results of PCT measurements are more readily available because it is an examination usually performed in urgent conditions, whereas the waiting period for the results of a $\mathrm{Ct}$ measurement is 
substantially longer. PCT could be a preliminary analysis allowing for assessment if a patient is at high or low risk of recurrence, and consequently used to decide if basic imaging (thyroid ultrasonography, chest radiography) is sufficient or if comprehensive scanning for localisation of metastases is needed.

According to our results, the correlation between Ct and PCT levels is extremely high with a Spearmans' rank coefficient approaching 1 . Association between $\mathrm{Ct}$ and PCT levels was very high in patients in remission as well as in patients with disseminated neoplastic disease. Both markers achieved the same sensitivity and specificity.

There were few previously published studies on the topic of the application of PCT in the diagnostics of recurrence of MTC. Most of them reported high very high sensitivity of PCT, ranging from 84.0 [13] to $100.0 \%[11,15,18,19]$ with more differentiated values of specificity — from 57 [18] to $100 \%$ [20]. The mentioned studies adapted different cut-off levels of PCT - from 0.1 to $0.5 \mathrm{ng} / \mathrm{mL}$. To our knowledge, the current study is the first one that not only assesses the diagnostic value of PCT but also compares it with other available markers of MTC.

As well as calcitonin, there are also some non-specific markers of MTC such as CEA or chromogranin A. It is recommended to monitor these markers to detect recurrence of poorly differentiated MTC with low expression of calcitonin; CEA is most commonly recommended as such an additional marker [2]. According to our results, despite quite strong correlation between CEA and $\mathrm{Ct}$ levels, the specificity and especially sensitivity of CEA is much lower. In more than one-third of patients with active MTC CEA was within the normal range, including individual with massive recurrence in the thyroid bed and metastases to the lymph nodes and lungs with a calcitonin level of almost $3000 \mathrm{pg} / \mathrm{mL}$ and CEA under $2 \mathrm{ng} / \mathrm{mL}$. This observation provides evidence that even in patients with very advanced MTC CEA can be falsely negative.

The sensitivity achieved for chromogranin A was slightly better than for CEA with lower specificity. However, the threshold for $\mathrm{CgA}$ determined with the use of ROC (receiver operating characteristic) curve was within the normal range for healthy person. Therefore, the use of such a threshold can be considered controversial, especially because the CgA level can increase above the normal range due to numerous non-neoplastic conditions, such as treatment with inhibitors of proton pump, liver failure, heart failure, inflammatory bowel diseases, stress, intensive physical activity, etc. [21, 22]. Only a minority of our patients with MTC had undoubtedly increased levels of $\mathrm{CgA}$; less than one third had results exceeding twice the upper limit of the normal range, and such an elevation of $\mathrm{CgA}$ was characteristic for patients with very advanced metastatic MTC.

In conclusion, our study confirms that PCT can be considered as an equivalent alternative of calcitonin in the case of patients with MTC. On the other hand, it is also worth remembering that MTC can be a rare cause of very high levels of PCT not resulting from infectious diseases. The diagnostic value of CEA and chromogranin A is much lower and can be within the normal range even in patients with advanced, metastatic MTC. They can be used only as accessory markers; CEA seems to be more valuable in this role due to its higher sensitivity.

\section{References}

1. Krysiak R, Marek B, Okopień B. Medullary thyroid cancer - the present state of art. Endokrynol Pol. 2008; 59: 446-455.

2. Wells SA Jr, Asa SL, Dralle H, et al. American Thyroid Association Guidelines Task Force on Medullary Thyroid Carcinoma. Revised American Thyroid Association guidelines for the management of medullary thyroid carcinoma. Thyroid. 2015; 25: 567-610.

3. Gimm O. Thyroid cancer. Cancer Lett 2001; 163: 143-156.

4. Favia G, Iacobone M. Medullary thyroid cancer: state of the art. G Chir 2005; 26: 405-409.

5. Rossi ED, Bizzarro T, Martini M, et al. The evaluation of miRNAs on thyroid FNAC: the promising role of miR-375 in follicular neoplasms. Endocrine. 2016 Jan 27. [Epub ahead of print]

6. Woliński K, Rewaj-Łosyk M, Ruchała M. Sonographic features of medullary thyroid carcinomas--a systematic review and meta-analysis. Endokrynol Pol. 2014; 65: 314-318.

7. Raue F, Frank-Raue K. Long-Term Follow-up in Medullary Thyroid Carcinoma. Recent Results Cancer Res. 2015; 204: 207-225.

8. Jarząb B, Dedecjus M, Handkiewicz-Junak D, et al. Diagnostics and Treatment of Thyroid Carcinoma. Endokrynol Pol. 2016; 67: 74-145.

9. Czepczyński R, Matysiak-Grześ M, Gryczyńska M, et al. Peptide receptor radionuclide therapy of differentiated thyroid cancer: efficacy and toxicity. Arch Immunol Ther Exp (Warsz). 2015 Apr;63(2): 147-54.

10. Kunikowska J, Ziemnicka K, Pawlak D, et al. Medullary thyroid carcinoma - PET/CT imaging with 68Ga-labelled gastrin and somatostatin analogues. Endokrynol Pol. 2016; 67: 68-71.

11. Kaczka K, Mikosiński S, Fendler W, Jałocha-Kaczka A, Pomorski L. Can procalcitonin be useful for medullary thyroid cancer? Endokrynol Pol. 2010; 61: 430-436

12. Kaczka K, Fendler W, Borowiec M, et al. One-step nucleic acid amplification testing in medullary thyroid cancer lymph nodes: a case series. Arch Med Sci. 2015; 11: 137-141.

13. Davies J. Procalcitonin. J Clin Pathol. 2015; 68: 675-679.

14. Trimboli P, Seregni E, Treglia G, Alevizaki M, Giovanella L. Procalcitonin for detecting medullary thyroid carcinoma: a systematic review. Endocr Relat Cancer. 2015; 22: R157-164

15. Kaczka K, Mikosiński S, Fendler W, Celnik A, Pomorski L. Calcitonin and procalcitonin in patients with medullary thyroid cancer or bacterial infection. Adv Clin Exp Med. 2012; 21: 169-178.

16. Plebani M \& Fabbri LM. Procalcitonin-guided antibiotic therapy: a potentially effective and efficient strategy. Clin Chem Lab Med 2015; 53:519-520.

17. Walter MA, Meier C, Radimerski T, et al. Procalcitonin levels predic clinical course and progression-free survival in patients with medullary thyroid cancer. Cancer 2010; 116: 31-40.

18. Bolko P, Manuszewska-Jopek E, Michałek K, Waśko R, Jaskuła M, Sowiński J. Efficacy of procalcitonin measurement in patients after total thyroidectomy due to medullary thyroid carcinoma Arch Immunol Ther Exp (Warsz). 2003; 51: 415-419.

19. Kratzsch J, Petzold A, Raue F, et al. 2011 Basal and stimulated calcitonin and procalcitonin by various assays in patients with and without medullary thyroid cancer. Clinical Chemistry 57 467-464.

20. Algeciras-Schimnich A, Preissner CM, Theobald JP, Finseth MS, Grebe SK. Procalcitonin: a marker for the diagnosis and follow-up of patients with medullary thyroid carcinoma. Journal of Clinical Endocrinology and Metabolism 2009; 94: 861-868.

21. Louthan O. Chromogranin a in physiology and oncology. Folia Bio (Praha). 2011; 57: 173-181.

22. Gut P, Czarnywojtek A, Fischbach J, et al. Arch Med Sci. 2016; 12: 1-9. 